\title{
APPLICATION OF QUANTUM TEACHING LEARNING MODEL AS AN EFFORT TO IMPROVE STUDENT LEARNING OUTCOMES
}

\author{
Annasari Siregar \\ SDN 22 Bathin Solapan, Riau, Indonesia \\ annasarisiregar@gmail.com
}

\begin{abstract}
Low student learning outcomes are a problem in schools, including where researchers teach. As an effort to improve student learning outcomes is the application of the quantum teaching learning model. This research was conducted on fifth grade students of SDN 022 Bathin Solapan with a total of 35 students. This research is a classroom action research. The instrument used was a learning outcome test. The results of this study found that the average initial data of students was 59.71 with 11 students who completed, in the first cycle, there was an increase with the average student learning outcomes being 68.14 with 23 students who achieved mastery, in cycle II student learning outcomes have reached the expected success indicators, namely the average student learning outcomes amounted to 75.28 with 32 students who were able to achieve the minimum passing criteria. The conclusion that can be drawn is that the application of the quantum teaching learning model can improve student learning outcomes.
\end{abstract}

Keywords: quantum teaching, learning outcomes

\section{PENERAPAN MODEL PEMBELAJARAN QUANTUM TEACHING SEBAGAI UPAYA MENINGKATKAN HASIL BELAJAR SISWA}

\begin{abstract}
ABSTRAK
Rendahnya hasil belajar siswa menjadi permasalahan yang ada di sekolah tidak terkecuali di tempat peneliti mengajar. Sebagai upaya dalam meningkatkan hasil belajar siswa adalah dengan penerapan model pembelajaran quantum teaching. Dalam model pembelajaran ini dikenal istilah TANDUR dimana siswa terlibat aktif dalam pembelajaran meliputi Tumbuhkan, Alami, Namai, Demonstrasikan, Ulangi, dan Rayakan. Penelitian ini dilaksanakan pada siswa kelas V SDN 022 Bathin Solapan dengan jumlah siswa sebanyak 35 orang. Penelitian ini merupakan penelitian tindakan kelas. Instrumen yang digunakan adalah tes hasil belajar. Hasil penelitian ini menemukan rata-rata data awal siswa adalah 59.71 dengan jumlah siswa yang tuntas sebanyak 11 orang, pada siklus I mengalami peningkatan dengan rata-rata hasil belajar siswa menjadi 68.14 dengan bayaknya siswa yang mencapai ketuntasan adalah 23 orang, pada siklus II hasil belajar siswa telah mencapai indikator keberhasilan yang diharapkan yakni rata-rata hasil belajar siswa adalah sebesar 75.28 dengan 32 orang siswa yang mampu mencapai kriteria kelulusan minimal. Kesimpulan yang dapat ditarik adalah bahwa penerapan model pembelajaran quantum teaching dapat meningkatkan hasil belajar siswa.
\end{abstract}

Kata Kunci: quantum teaching, hasil belajar

\begin{tabular}{|c|c|c|}
\hline Submitted & Accepted & Published \\
\hline 17 Juli 2020 & 10 September 2020 & 26 September 2020 \\
\hline
\end{tabular}

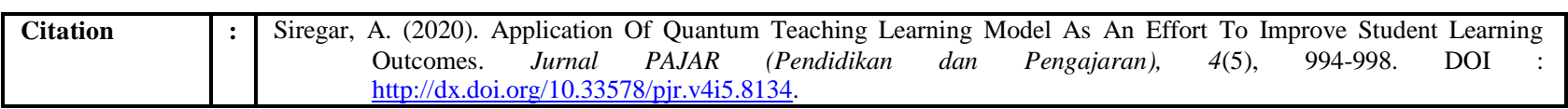

\section{PENDAHULUAN}

Salah satu pengukuran keberhasilan pembelajaran adalah melalui hasil belajar. Banyak ditemukan di lapangan bahwa hasil belajar siswa rendah. Hal ini bisa disebabkan banyak faktor baik internal maupun eksternal. Untuk itu guru harus melakukan berbagai upaya dalam meningkatkan hasil belajar siswa. Kendala yang sering ditemukan adalah ada pengajar yang belum dapat memilih, menentukan, menerapkan dan mengoptimalkan model pembelajaran sebagai komponen dari sistem adaptif sesuai kebutuhan siswa. Banyak pembelajaran dengan dominasi ceramah tanpa banyak melibatkan aktifitas dan penggalian kemampuan siswa.

Fakta di lapangan yang ditemukan dari studi pendahuluan bulan januari mencerminkan bahwa proses pembelajaran tidak menarik minat dan motivasi siswa untuk menemukan sendiri 
jawaban yang disajikan atau memecahkan masalah yang dihadapi. Siswa cenderung pasif dalam artian hanya menerima informasi dari guru tanpa dapat menggali pengetahuan dari sumber lain atau berdasarkan pencarian oleh siswa. Hasil belajar siswa pada mata pelajaran IPA materi pesawat sederhana masih rendah dan banyak yang belum mengetahui jenis dan fungsi pesawat sederhana dalam kehidupan sehari-hari.

Sebagai upaya dalam meningkatkan hasil belajar siswa adalah melalui penerapan model pembelajaran quantum teaching. Model pembelajaran ini merupakan model pembelajaran dengan menyajikan latar belakang dan strategi untuk meningkatkan pembelajaran dan menjadikan suasana belajar lebih menyenangkan (Acat, 2014). Peneliti berharap dengan dilakukannya penerapan pembelajaran quantum teaching ini dapat meningkatkan hasil belajar siswa. Karena model pembelajaran ini mengoptimalkan proses dan hasil belajar dengan cara mengupayakan ketertarikan siswa untuk belajar, memotivasinya, dan menumbuhkan kepercayaan diri siswa melalui pengorganisasian siswa oleh guru (Merthayasa, dkk. (2016). Siswa ditumbuhkan rasa ingintahunya kemudian melakukan kegiatan untuk menjawab rasa ingin tahu tersebut.

\section{KAJIAN TEORETIS \\ Model Pembelajaran Quantum Teaching}

Proses pembelajaran di kelas dapat berjalan dengan baik apabila dilakukan perencanaan yang matang dan dilaksanakan dengan pembelajaran yang dapat memecahkan permasalahan yang dihadapi siswa. Dalam pembelajaran, guru harus mampu mempertimbangkan situasi dan kondisi siswa yang diajar, kemampuan siswa, fasilitas pengajaran dan pembelajaran, serta karakteristik siswa. Salah satu model pembelajaran yang baik untuk meningkatkan aktifitas dan hasil belajar siswa adalah quantum teaching yakni pembelajaran yang menyenangkan dengan upaya melakukan kombinasi kegiatan mental yang menekankan pada fisiologi relaks, pada akhirnya siswa belajar dengan gembira yang nantinya melahirkan siswa yang istimewa (Qalsum, 2018).

Model pembelajaran quantum teaching melibatkan segala interaksi yang mencakup berbagai unsur yang dapat mempengaruhi proses pembelajaran sehingga membantu siswa dalam memahami pelajaran. Interaksi yang dilakukan akan menciptakan pembelajaran yang menyenangkan dan berkesan bagi siswa, lebih dari itu siswa juga mendapatkan pengalaman langsung melalui kegiatan pembelajaran. Kegiatan pembelajaran dalam quantum teaching dikenal dengan istilah TANDUR (Tumbuhkan, Alami, Namai, Demonstrasikan, Ulangi, dan Rayakan). Kegiatan yang dilakukan selama proses pembelajaran IPA dapat diawali oleh guru untuk menumbuhkan minat siswa dengan melakukan demonstrasi atau pertanyaan pembuka mengenai materi yang akan dipelajari, kemudian siswa mengalami langsung dengan melakukan kegiatan pembelajaran serta memberikan atau sekedar mengetahui nama dari suatu yang dipelajari, kemudian dapat melakukan demonstrasi dan mengulangi sampai menghasilkan pengetahuan dan keterampilan baru yang pada akhirnya mendapatkan penghargaan dan dirayakan secara bersama-sama atas pencapaian yang dihasilkan siswa.

\section{Hasil Belajar}

Hasil belajar dapat diartikan sebagai pencapaian siswa pada akhir pembelajaran dalam bentuk huruf atau angka (Reich, 2015) dan (Sriarunrasmee, 2015) yang merupakan hasil akhir dari proses yang telah dilakukan (Lile, 2014). Hasil belajar dapat dijadikan sebagai patokan dalam menjamin kualitas pendidikan hingga dapat mengungkap pendidikan secara luas (Maher, 2004). Dapat ditarik kesimpulan bahwa pencapaian akhir siswa dalam bentuk angka maupun huruf yang merupakan dampak dari proses pembelajaran merupakan hasil belajar.

\section{METODE PENELITIAN}

Penelitian ini dilaksanakan di kelas 5 SDN 022 Bathin Solapan pada semester genap tahun ajaran 2019-2020. Keseluruhan siswa berjumlah 35 
orang dengan 18 siswa perempuan dan 17 siswa laki-laki. Kelas ini menjadi subjek penelitian setelah dipilih secara acak. Penelitian ini merupakan penelitian tindakan kelas.

Metode Pengumpulan dan Pengolahan Data

Instrumen penelitian berupa tes hasil belajar siswa. Data yang dikumpulkan bersumber dari aktifitas pembelajaran dan hasil belajar siswa kelas 5 SDN 022 Bathin Solapan. Setelah data terkumpul maka dilakukan analisis secara kualitatif dan data hasil belajar dianalisis secara kuantitatif deskriptif. Hasil belajar siswa dikategorikan dalam tabel berikut:

Tabel 1. Kategori Hasil Belajar Siswa

\begin{tabular}{cc}
\hline Interval & Kategori \\
\hline $85-100$ & Sangat Tinggi \\
$71-85$ & Tinggi \\
$56-70$ & Sedang \\
$41-55$ & Rendah \\
\hline
\end{tabular}

(dalam Asmurni 2019)

Indikator keberhasilan dalam penelitian ini adalah sebanyak $90 \%$ hasil belajar siswa mencapai nilai rata-rata 70

\section{HASIL DAN PEMBAHASAN}

Gambaran mengenai hasil belajar siswa kelas 5 SDN 022 Bathin Solapan pada prasiklus dan siklus diterapkan model pembelajaran quantum teaching pada materi pesawat sederhana disajikan pada tabel 2 berikut

Tabel 2. Ringkasan Hasil Belajar Siswa dalam Penerapan Model Pembelajaran Quantum Teaching

\begin{tabular}{ccccc}
\hline \multirow{2}{*}{ No. } & Keterangan & Data Awal & \multicolumn{2}{c}{ Sesudah Tindakan } \\
& & & Siklus I & Siklus II \\
\hline 1. & Nilai tertinggi & 75 & 80 & 85 \\
2. & Nilai terendah & 25 & 35 & 55 \\
3. & Rata-rata & 59.71 & 68.14 & 75.28 \\
4. & Ketuntasan (Siswa) & 11 & 23 & 32 \\
\hline
\end{tabular}

Penelitian ini diawali dengan melihat sejauh mana kemapuan siswa berupa hasil belajar sebelum diberikan pembelajaran quantum teaching. Data awal menunjukkan bahwa rata-rata hasil belajar siswa adalah sebesar 59.71 yang masih jauh dari indikator keberhasilan yang diharapkan, selain itu hanya terdapat 11 siswa yang mencapai standard keberhasilan yang ditetapkan. Nilai terendah yang diperoleh siswa adalah sebesar 25 dan yang tertinggi hanya mencapai 75. Hal ini menggambarkan bahwa hasil belajar siswa masih rendah.
Berdasarkan data awal, maka peneliti memberikan tindakan berupa model pembelajaran quantum teaching yang diharapkan dapat memperbaiki proses pembelajaran yang menghasilkan hasil belajar yang baik. Perlakuan peneliti diawali dengan menyajikan pertanyaan sederhana terkait materi pesawat sederhana berupa "pernahkah kamu bermain jungkat jungkit?" "bagaimana model/bisakah kamu menggambarkan orang bermain jungkat jungkit?" "mengapa kita teman kita dapat terangkat dengan 
mudah saat bermain jungkat jungkit dibandingkan dengan kita mengangkat secara langsung?".

Melalui pertanyaan pembuka, siswa tertarik untuk menggali informasi yang ada dalam pikirannya serta berupaya mengungkapkan kepada guru dan siswa lainnya. Sehingga guru dapat mengarahkan siswa untuk melakukan kegiatan berupa penamaan dan demonstrasi sesuai kegiatan pembelajaran yang telah dirancang, setelah semua siswa mengalami proses pembelajaran maka secara bersama-sama merayakan capaian pembelajaran yang telah diperoleh siswa. Siswa layak mendapatkan apresiasi atas keberhasilan yang mereka capai (Rahmawati, 2017).

Setelah pembelajaran siklus I dilaksanakan, hasil pembelajaran mengalami peningkatan yang baik dimana rata-rata siswa memperoleh hasil belajar sebesar 68.14 dengan jumlah siswa yang tuntas sebanyak 23 orang. Hasil ini lebih baik dari data awal namun penelitian belum dapat dinyatakan berhasil karena belum mencapai indikator keberhasilan yakni sebanyak 90\% siswa mencapai kriteria kelulusan minimal yakni 70.

Pada siklus II, peneliti lebih optimal dalam menerapkan model pembelajaran quantum teaching pada setiap tahapan TANDUR. Pada tahapan tumbuhkan, guru menyajikan 2 video yang pertama berupa seorang tukang bangunan mengangkat pasir menggunakan ember dan kedua seorang tukang mengangkat pasir menggunakan angkong. Kemudian peneliti mengajukan pertanyaan "jika kedua beban pasir sama berat, mengapa tukang yang mengangkat pasir menggunakan ember merasa kesulitan dan keberatan dibandingkan dengan tukang yang mengangkat pasir menggunakan angkong?" setelah terjadi diskusi maka pada kegiatan inti guru meminta siswa untuk melakukan 2 kegiatan yakni 1 mengangkat tas berisi dengan berat $2 \mathrm{~kg}$ ke atas meja tanpa bantuan alat pesawat sederhana, dan 2 mendorong tas dengan bidang miring dari bawah ke atas meja. Siswa diminta melakukan demonstrasi dan melakukan perbandingan yang pada akhirnya menyimpulkan berdasarkan kegiatan yang mereka lakukan. Setelah siswa menemukan jawaban berdasarkan bimbingan guru maka siswa dapat merayakannya bersama-sama.
Pembelajaran ini lebih bermakna karena relevan bagi kehidupan siswa (Suryani, 2013).

Hasil belajar pada siklus II mengalami peningkatan yang signifikan dari siklus sebelumnya dimana rata-rata hasil belajar yang diperoleh siswa adalah 75.28 dengan jumlah siswa yang tuntas sebanyak 32 orang. Pencapaian tertinggi adalah 85 yang dicapai oleh 7 orang siswa. Pencapaian ini menggambarkan bahwa model pembelajaran quantum teaching dapat meningkatkan hasil belajar siswa (Mufarrid, 2020). Hal ini didukung oleh penelitian Yanuarti (2016) yang menyatakan bahwa model pembelajaran quantum teaching dapat meningkatkan hasil belajar siswa serta lebih unggul daripada model pembelajaran discovery learning.

\section{SIMPULAN DAN REKOMENDASI}

Berdasarkan hasil penelitian tersebut dapat ditarik kesimpulan bahwa penerapan model pembelajaran quantum teaching dapat meningkatkan hasil belajar siswa kelas V SDN 022 Bathin Salopan dengan nilai rata-rata data awal sebesar 59.71 dengan jumlah siswa yang tuntas sebanyak 11 orang menjadi rata-rata sebesar 68.14 dengan jumlah ketuntasan siswa sebanyak 23 orang pada siklus I. kemudian mengalami peningkatan yang signifikan pada siklus II dengan capaian rata-rata sebesar 75.28 dengan jumlah 32 orang siswa yang mencapai KKM.

Rekomendasi yang dapat dilakukan oleh peneliti selanjutnya adalah agar guru lebih mempersiapkan kebutuhan dalam belajar misal video pembelajaran atau alat peraga sehingga siswa dapat melihat dan melakukan demonstrasi secara langsung dan dapat memperoleh jawaban dari kegiatan yang mereka lakukan.

\section{DAFTAR PUSTAKA}

Acat, M, B. (2014). An Investigation the Effect of Quantum Learning Approach on Primary School 7th Grade students' Sciencs Achievement, Retention and Attitude. Educational Research Assosiation the International Journal of Reasearch in Teacher Education , 5 (2), 11-23. 
Asmurni. (2019). Keefektifan Model Pembelajaran Kontruktivisme dalam Meningkatkan Hasil Belajar IPA Siswa Kelas VI SD Negeri 003 Benai Kecil. Jurnal PAJAR (Pendidikan dan Pengajaran), 3 (5), 9951002.

Lile, R. (2014). The Assessment of Learning Outcomes. Procedia - Social and Behavioral Sciences, 163, 125-131.

Maher, A. (2004). Learning Outcomes in Higher Education: Implications forCurriculum Design and Student Learning. Journal of Hospitality, Leisure, Sport and Tourism Education , 3 (2), 47.

Merthayasa, I, N, W., Putra, I, K, A., dan Suadnyana, I, N. (2016). Penerapan Model Quantum Teaching untuk Meningkatkan Hasil Belajar Bahasa Indonesia (Keterampilan Menulis) pada Siswa Kelas IV SD. e-Journal PGSD Universitas Pendidikan Ganesha, 4 (1), 1-9.

Mufarrid, H., dan Yalvema. (2020). Improving the Science Learning Outcomes of Elementary School Student Using Quantum Teaching. Jurnal Pendidikan Guru Sekolah Dasar, 9 (2), 185-193

Qalsum, U. (2018). Penerapan Metode Quantum Learning dalam Upaya Meningkatkan Hasil Belajar Siswa Kelas VIII.A SMP Pesantren Datok Sulaiman Palopo Khususnya Pembelajaran Bahasa Indonesia. Jurnal Onoma: Pendidikan, Bahasa, dan Sastra, 4 (2), 92-104.

Rahmawati, S. (2017). Upaya Meningkatkan Hasil Belajar IPA Melalui Model Pembelajaran Quantum Teaching Siswa Kelas V SD Negeri Pilahan Yogyakarta Tahun Pelajaran 2016/2017. Trihayu: Jurnal Pendidikan Ke-SD-an, 4 (1), 268-272.

Reich, A. (2015). Is the Road to Effective Assessment of Learning Outcomes Paved With Good Intentions? Understanding the Roadblocks to Improving Hospitality Education. Journal of Hospitality, Leisure, Sport, \& Tourism Education, 18, 21-23.

Sriarunrasmee, J. (2015). Virtual Field Trips with Inquiry Learning and Critical Thinking Process: A Learning Model to Enhance
Students' Sciences Learning Outcomes. Procedia-Social and Behaviour Sciences, 197, 1721-1726.

Suryani, N. (2013). Improvement of Student History Learning Competence through Quantum learning Model. Journal of Education and Practice , 4 (14), 55-63.

Yanuarti, A., dan Sobandi, A. (2016). Upaya Meningkatkan Hasil Belajar Siswa Melalui Penerapan Model Pembelajaran Quantum Teaching. Jurnal Pendidikan Manajemen Perkantoran, 1 (1), 11-18. 